\title{
Some aspects of reproductive health and metabolic disturbances in pregnant women and their newborn in ecologically injurious conditions of an industrial city in the Urals
}

\author{
L. A. Kovalchuk ${ }^{1,2}$, A. E. Tarkhanova ${ }^{1,3,4}$ \& A. A. Tarkhanov ${ }^{1,3,5}$ \\ ${ }^{I}$ Middle Urals Scientific Center, Russian Academy of Medical Sciences, \\ Laboratory of Adaptation Problems, Russia \\ ${ }^{2}$ Institute of Ecology, Ural Branch Russian Academy of Sciences, Russia \\ ${ }^{3}$ The Ural State Medical Academy, Russia \\ ${ }^{4}$ Municipal Hospital 1, Russia \\ ${ }^{5}$ Dispensary of Oncology, Sverdlovsk Region, Yekaterinburg, Russia
}

\begin{abstract}
Medico-social aspects of the reproductive health of women are actual during the last decade in connection with the critical demographic tendency in Russia. Women of Ekaterinburg have disturbed reproductive functions and pregnancy complications (hestoses, danger of pregnancy break) Up to $80 \%$ of inspected women had somatic pathology. The leading among diseases are anemia, chronic infections inflammatory diseases, kidney and endocrine diseases and various forms of mastopathy.

Therefore, health protection, especially of women and newborn is of special importance in ecologically unfavourable regions, including the Urals. Considering the fact that technogenic pollution consequences instantly dangerously affect the health of a mother and a child, we investigated the "mother-placenta-fetus" biological system. In the blood serum and placenta tissue of all inspected pregnant women in Ekaterinburg concentration of trace elements $(\mathrm{Cu}, \mathrm{Zn}, \mathrm{Cd}, \mathrm{Pb}, \mathrm{Ca}, \mathrm{Cr}, \mathrm{Ni}(\mathrm{p}<0,05)$ were higher compared with the data for other regions.

The deficiency of essential trace elements $(\mathrm{Cu}, \mathrm{Fe}, \mathrm{Zn}, \mathrm{Mg}, \mathrm{Ca})$ and accumulation of toxic $\mathrm{Cd}$ and $\mathrm{Pb}$ in the umbilical cord blood were the reason for the intrauterine sufferings of a fetus responsible for the low body mass at birth,
\end{abstract}


retardation of growth and development. The disturbance of fetal and infant development frequently disturbed the early neonatal adaptation and underlied many subsequent diseases.

Keywords: reproductive health, pregnant women, newborn, blood serum, placenta, trace elements.

\section{Introduction}

Ecologically dependent pathologies of the population, including pregnant women and the newborn have grown in industrially developed countries during last decades. Numerous publications, including annual reports of the World Health Organization expert committees, show that $20-25 \%$ of the population's health depends on environmental conditions. It is known that in most industrial cities of the Russian Federation the environmental pollution with many harmful substances scores of times exceeds the maximum permissible concentration [1].

Medico-social aspects of the reproductive health of women have become urgent at present in connection with the extremely negative demography trend in Russia. It makes us pay special attention to the reasons for the increased instances of perinatal morbidity and mortality $[2,3]$.

The most important factors causing the high obstetric risk during pregnancy and influencing the demography are the ecological situation and population health in large industrial cities.

The Ural region long ago became a zone of ecological risk concerning heavy metals and radiation pollution [4-8]. The medico-ecological situation in this region is unfavourable. In Severdlovsk region every second pregnancy; in Ekaterinburg, every third has burdened obstetric and gynecologic anamnesis [9]. A good state of the feto-placentary complex is responsible for the bearing and birth of a healthy child [10-12].

As participation of essential (Fe, $\mathrm{Mg}, \mathrm{Mn}, \mathrm{Ca}, \mathrm{Cu}, \mathrm{Zn}, \mathrm{Ni}, \mathrm{Cr}$,) and toxic $(\mathrm{Cd}$, $\mathrm{Pb}$ ) microelements in the course of pregnancy is doubtless, the problem of their toxicity for an embryo and fetus is very important. A growing number of women inhabiting megacities is affected by various combinations of these elements. Thus all districts of Ekaterinburg are polluted with heavy metals (HM).

At present there are many problems of trace element metabolism, there are no exact data on adaptation to them [13-16]. Shortage of facts does not allow us to uniformly explain underlying mechanisms of trace elements participation in homeostasis; theoretic discoveries are not introduced in clinical practice.

In conditions of environmental pollution with hazardous compounds responsible for the embryo - and gonado - toxic effects the decrease and prevention of fetoplacental insufficiency cases is impossible without early diagnostics and preventive measures [12, 17-19].

\section{Cases and methods}

The research was made in the obstetric clinic on the basis of the maternity hospital of the central hospital of №1 in Ekaterinburg. We made a complex 
clinico-laboratory inspection of 156 pregnant women at the age of 17 to 42 and of their newborn, and a retrospective analysis of pregnancies, deliveries and newborn development,

A complex ultrasonic inspection of pregnant women included fetometry, evaluation of the fetal biophysical profile, dopplerometric estimation of the blood-stream in the umbilical cord arteries. For the echography and dopplerometry we used the "Aloka-1400" device. According to the ultrasonic and dopplerometric results, groups of inspected cases were formed,

The levels of microelements: $\mathrm{Fe}, \mathrm{Ca}, \mathrm{Mg}, \mathrm{Mn}, \mathrm{Ni}, \mathrm{Cr}, \mathrm{Zn}, \mathrm{Cu}, \mathrm{Cd}, \mathrm{Pb}$ in the placenta, tissues, blood serum of women, and in the umbilical blood of the newborn were analyzed in triplicate and estimated by atomic absorption spectrophotometry (Perkin Elmer Analyst 1000, USA) and by atomic absorption ("AAS" spectrophotometer, Germany). Separate and disposable sterilized plastic syringes were used for blood collection. A blood sample was left standing for one hour to coagulate; serum was separated at $2000 \mathrm{rpm}$ centrifugation for 10 minutes, transferred to a $5 \mathrm{ml}$ polystyrene tube and stored at $-18^{\circ} \mathrm{C}-20^{\circ} \mathrm{C}$ until the analysis.

A statistical analysis was carried out with the program "Statistica \& Microsoft Excel". Results were shown as a mean \pm standard error (SEM). Parameters showing Gaussian distribution were analyzed by Student's t-test. The MannWhitney U-test was used for parameters showing non-Gaussian distribution. The correlation between variables was evaluated by Pearson's correlation coefficients or Sperman's rank correlation coefficients were used to relate trace elements concentration, body mass and the fetal growth and medical data. The distinctions between the samples were considered to be statistically significant at $\mathrm{p}<0.05$.

\section{Results and discussion}

The object of the research was the biological system - "mother-placentanewborn". The basic group was 117 pregnant women constantly living in Ekaterinburg and their 117 newborn. The control group was 26 women constant residents of nonindustrial areas in Sverdlovsk region and their 26 newborn. The basic and the control groups were formed by the method of random sampling, with the account of ecological conditions of residence. The composition of groups was heterogenous; there were no professions with harmful working conditions.

The analysis of the obstetric anamnesis revealed the following data. In the basic group (Ekaterinburg residents) $81,25 \%$ had complicated obstetric and gynecologic anamnesis, somatic pathology and pregnancy complications. $65 \%$ had various extragenital diseases of an infectious-inflammatory character. Anemia $(50,4 \%)$, threats of pregnancy interruption $(13,7 \%)$ and hypertension unconnected with pregnancy were noted in $16 \%$. $18,8 \%$ of women had chronic pyelonephritis, $29,9 \%$ had hestosis.

In the control group (ecologically "safe" territories) physiologically proceeding pregnancy and delivery were observed in $69 \%$ of women. Complicated obstetric anamnesis and various complications of pregnancy were 
marked in $30,8 \% .100,0 \%$ of women from the control group had extragenital infections and noninfectious diseases. Complications of pregnancy were the following: Fe-deficit anemia $-50,0 \%$; chronic pyelonephritis $-25,0 \%$; hestosis $25,0 \%$; hypertension unconnected with pregnancy $-12,5 \%$.

In the basic group the number of complicated pregnancies and deliveries exceeded the frequency of complications among the newborn, the last in its turn was above that in the control group: immaturity, a syndrome of respiratory disturbance predominated in the newborn. In the basic group $18,7 \%$ of children were born healthy, chronic hypoxia of various degrees was observed in $81,2 \%$. Light hypoxia cases exceeded those in the control group 4,1 times; average degree cases $-2,0$ times; every fifth child had heavy hypoxia. In the basic group $75,0 \%$ of children had proportional physical development; $25,0 \%$ - had intrauterine growth restriction and $36,1 \%$ of them were born premature.

In the control group $92,3 \%$ of children had proportional physical development and $7,7 \%$ with intra-uterine growth restriction. Chronic hypoxia was observed in $30,8 \%$ of the newborn from the control group. In the control group there were no premature births.

Thus, considerably worse obstetric indices were observed in women living in ecologically unfavorable conditions in comparison with the women whose organisms were not affected by hazardous anthropogenous factors. Especially worse was the state of fetus and newborn - they exhibited the highest degree of hypoxia and intra-uterine growth restriction.

All sampled women, irrespective of the place of their residence, were subject to dopplerometry of placentary blood circulation during physiological and complicated pregnancy.

In somatically healthy women without complicated pregnancy no pathological curves of the blood-current in the umbilical cord artery were registered (Fig. 1a). Pregnant women with prenatal fetal pathology exhibited a lower diastolic component of the blood flow in the umbilical cord artery, and apparition dicrotics dimple in the phase of early diastole (Fig. 16.).

In cases of heavy prenatal fetal pathology - zero and reverse diastolic component of the blood flow in the umbilical cord artery were registered - a characteristic sign of heavy disturbances of fetoplacental blood circulation (Fig. 1в, Fig.1г.).

The analysis of haemodynamics in the umbilical cord artery revealed an increased sistolo-diastolic correlation in the group of pregnant city residents compared with the control group $(4,0 \pm 0,07$ and $2,4 \pm 0,03$ accordingly, $\mathrm{p}<0.05)$. Resistance indices also revealed worse fetal blood circulation in the city residents: $0,75 \pm 0,08$ in the basic group and $0,58+0,07$ in the control group $(\mathrm{p}<0.05)$. The research revealed considerably worse obstetric indices in the city residents: development of anaemia and the highest level of hypoxia and intrauterine growth restriction of fetus.

Thus, in comparison with the data from other regions, all pregnant of Ekaterinburg residents had higher levels of trace elements: $\mathrm{Cu}, \mathrm{Zn}, \mathrm{Cd}, \mathrm{Pb}, \mathrm{Sa}$, $\mathrm{Cr}, \mathrm{Ni}$ in the blood serum and placenta tissue $(\mathrm{p}<0,05)$. This corresponded to the results of other authors [20,21]. The levels of the essential microelements Mn, 


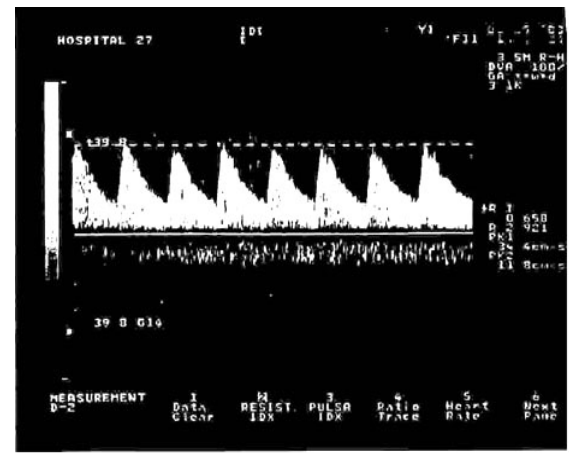

a

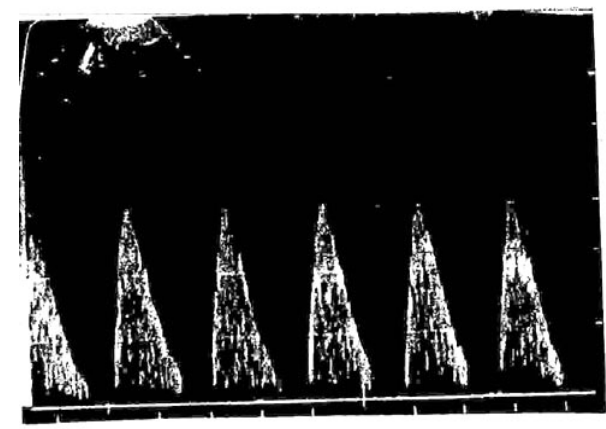

B

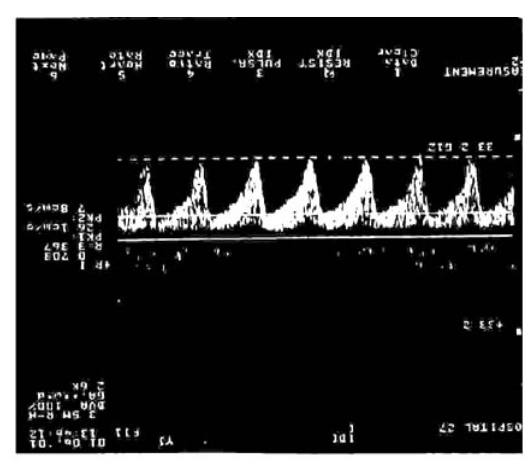

6

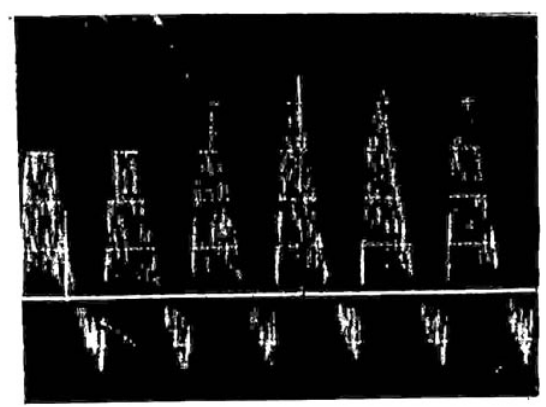

$\Gamma$

Figure 1: Dopplerometric indices of pregnant Ekaterinburg residents: a - healthy fetus; $\boldsymbol{0}$ - initial stage of placentary insufficiency; $\mathbf{B}-$ absence of diastolic component in all heart cycles; $\boldsymbol{\Gamma}$ - reverse diastolic component of the blood flow in all heart cycles.

$\mathrm{Mg}$ and Fe were significantly lower $(\mathrm{p}<0,01)$. Somatically healthy women of Ekaterinburg had significantly higher concentrations of heavy metals in placenta tissues, than somatically healthy women from the control group $(\mathrm{Cu}-1,8$ times, $\mathrm{Zn}-2,4$ times, $\mathrm{Cd}-14,0$ times, $\mathrm{Pb}-12,4$ times) (Table 1.).

A direct correlation was revealed between the levels of $\mathrm{Cd}$ in the city environment and in placentas of its pregnant residents $(\mathrm{r}=0.86 \mathrm{p}<0.05)$. For $\mathrm{Pb}$ the relationship had average values $(r=0.34 ; \mathrm{p}<0.05)$. Concentrations of ecotoxic cadmium and lead in the blood $(\mathrm{Cd}=0.03 \pm 0.006 ; \mathrm{Pb}=0.31 \pm 0.07)$ and placentas $(\mathrm{Cd}=0.084 \pm 0.014 ; \mathrm{Pb}=0.62 \pm 0.8)$ of somatically healthy pregnant city residents exceeded those in other technogenic territories and the European standard [22-24]. Permeability of placentary barrier to toxic lead was noted. At the same time placenta was a barrier for the penetration of raised concentrations of cadmium into the fetal organism, $\mathrm{Cd}$ a content in the umbilical blood of the newborn was lower compared to the mother's blood. 
Table 1: $\quad$ Trace elements in placentary tissues of megapolis (basic group) and unindustrial area (control) residents.

\begin{tabular}{|c|c|c|c|c|}
\hline $\begin{array}{c}\text { Trace element, } \\
\mathrm{mkg} / \mathrm{g}\end{array}$ & Group & $\mathrm{M}$ & $\mathrm{m}$ & $\mathrm{P}$ \\
\hline $\mathrm{Cu}$ & $\begin{array}{l}\text { basic } \\
\text { control }\end{array}$ & $\begin{array}{l}0.74 \\
0.42\end{array}$ & $\begin{array}{l}0.036 \\
0.012\end{array}$ & $\mathrm{~T}_{1-2}=7.9>\mathrm{T}_{099}=2.58$ \\
\hline $\begin{array}{c}\mathrm{Ca}, \\
\mathrm{Mmol} / 1\end{array}$ & $\begin{array}{c}\text { basic } \\
\text { control }\end{array}$ & $\begin{array}{l}8,82 \\
1,42 .\end{array}$ & $\begin{array}{l}1,05 \\
0,20\end{array}$ & $\mathrm{~T}_{1-2}=6.9>\mathrm{T}_{0.99}=2.58$ \\
\hline $\mathrm{Zn}$ & $\begin{array}{l}\text { basic } \\
\text { control }\end{array}$ & $\begin{array}{c}14.62 \\
6.10\end{array}$ & $\begin{array}{l}1.90 \\
0.28\end{array}$ & $\mathrm{~T}_{1-2}=4.3>\mathrm{T}_{099}=2.58$ \\
\hline $\mathrm{Fe}$ & $\begin{array}{c}\text { basic } \\
\text { Control }\end{array}$ & $\begin{array}{l}1.01 \\
3.54\end{array}$ & $\begin{array}{l}0.28 \\
0.12\end{array}$ & $\mathrm{~T}_{1-2}=8.4>\mathrm{T}_{099}=2.58$ \\
\hline $\mathrm{Mn}$ & $\begin{array}{l}\text { basic } \\
\text { control }\end{array}$ & $\begin{array}{l}0.37 \\
1.18\end{array}$ & $\begin{array}{l}0.02 \\
0.21\end{array}$ & $\mathrm{~T}_{1-2}=4.05>\mathrm{T}_{099}=2.58$ \\
\hline $\mathrm{Ni}$ & $\begin{array}{c}\text { basic } \\
\text { control }\end{array}$ & $\begin{array}{l}0.62 \\
0.45\end{array}$ & $\begin{array}{l}0.16 \\
0.09\end{array}$ & $\mathrm{~T}_{1-2}=0.9<\mathrm{T}_{099}=2.58$ \\
\hline $\mathrm{Cr}$ & $\begin{array}{l}\text { basic } \\
\text { control }\end{array}$ & $\begin{array}{l}0.98 \\
0.27\end{array}$ & $\begin{array}{l}0.11 \\
0.03\end{array}$ & $\mathrm{~T}_{1-2}=6.3>\mathrm{T}_{099}=2.58$ \\
\hline $\mathrm{Cd}$ & $\begin{array}{c}\text { basic } \\
\text { control }\end{array}$ & $\begin{array}{l}0.084 \\
0.006\end{array}$ & $\begin{array}{c}0.01 \\
0.001\end{array}$ & $\mathrm{~T}_{1-2}=6.5>\mathrm{T}_{099}=2.58$ \\
\hline $\mathrm{Pb}$ & $\begin{array}{l}\text { basic } \\
\text { control }\end{array}$ & $\begin{array}{l}0.62 \\
0.05\end{array}$ & $\begin{array}{c}0.08 \\
0.014\end{array}$ & $\mathrm{~T}_{1-2}=7.1>\mathrm{T}_{099}=2.58$ \\
\hline $\begin{array}{c}\mathrm{Mg}, \\
\mathrm{Mmol} / 1\end{array}$ & $\begin{array}{l}\text { basic } \\
\text { control }\end{array}$ & $\begin{array}{l}0.61 \\
1.22\end{array}$ & $\begin{array}{l}0.14 \\
0.20\end{array}$ & $\mathrm{~T}_{1-2}=2.5>\mathrm{T}_{099}=1.96$ \\
\hline
\end{tabular}

The distribution of H.M. in biosubstrata "mother-placenta-newborn" has the character of correlations of concentrations of industrial metals (Table 2.). Thus, concentrations of $\mathrm{Cu}, \mathrm{Pb}, \mathrm{Zn}$ ions quantitavely correlate; there is a direct relationship $(r=0,613 ; r=0,501 ; r=0,609$ accordingly at $p<0,05)$ in their level between the mother's and newborn's blood (Kovalcuk et al. [8]. Correlation analysis shows that the distribution and accumulation of H.M. in the fetal and newborn organism is significantly dependent on the concentration of metals in the mother's blood. Thus, for $\mathrm{Cd}$ levels there is a significant relationship between the blood serum and placenta tissue of pregnant women $(r=0,567$ at $\mathrm{p}<0,05)$ but no correlation in the system "mother's placenta - newborn's blood" $(\mathrm{r}=0,098$ at $\mathrm{p}<0,05)$ and mother's blood - newborn's blood $(\mathrm{r}=0,140$ at $\mathrm{p}<0,05)$.

The high extragenital morbidity among city residents, frequent complications during pregnancy and delivery, the observed imbalance of trace elements in 
Table 2: Correlation of trace element concentrations in the biological system "mother-placenta-newborn".

\begin{tabular}{|c|c|c|c|}
\hline $\begin{array}{c}\text { Trace } \\
\text { element }\end{array}$ & Factor & $\begin{array}{c}\text { Correlation } \\
\text { coefficient, } \mathrm{r}\end{array}$ & $\mathrm{P}$ \\
\hline $\mathrm{Cu}$ & $\begin{array}{c}\text { mother's blood - placenta } \\
\text { placenta - newborn's blood } \\
\text { mother's blood - newborn's } \\
\text { blood }\end{array}$ & $\begin{array}{c}0.117 \\
0.173\end{array}$ & 0.05 \\
& $\mathbf{0 . 6 1 3}$ & 0.05 \\
& mother's blood - placenta & 0.157 & 0.01 \\
\hline $\mathrm{Zn}$ & placenta - newborn's blood & -0.190 & 0.05 \\
& mother's blood - newborn's & $\mathbf{0 . 6 0 9}$ & 0.05 \\
& blood & 0.136 & 0.01 \\
$\mathrm{~Pb}$ & mother's blood - placenta & 0.160 & 0.01 \\
& placenta - newborn's blood & $\mathbf{0 . 5 0 1}$ & 0.05 \\
& mother's blood - newborn's & & 0.01 \\
$\mathrm{Cd}$ & mother's blood - placenta & $\mathbf{0 . 5 6 7}$ & 0.05 \\
& placenta - newborn's blood & 0.098 & 0.05 \\
& mother's blood - newborn's & 0.140 & \\
\hline
\end{tabular}

homeostasis showed that the system "mother-placenta-newborn" was a single functional structure depending on ecological environmental conditions and was responsible for the health of progeny.

We marked a spatial correlation between children's pathology and centres of environmental pollution with heavy metals $(r=0.63 ; p<0.05)$. In the basic group placentary insufficiency was accompanied by the deficiency of essential elements: $\mathrm{Fe}, \mathrm{Cu}, \mathrm{Ca}, \mathrm{Zn}, \mathrm{Mg}$ in blood of the newborn during the first hours after birth. In the blood of these children levels of $\mathrm{Cd}$ increased 5 times $(0,02 \pm 0,001$ $\mathrm{mkg} / \mathrm{ml})$ concentrations of lead -1.9 times $(0,29 \pm 0,07 \mathrm{mkg} / \mathrm{ml})$ against the background of lower levels of the essential microelements: $\mathrm{Cu}(0,68 \pm 0,085$ $\mathrm{mkg} / \mathrm{ml}), \mathrm{Zn}(1,4 \pm 0,95 \mathrm{mkg} / \mathrm{ml}), \mathrm{Fe}(0,81 \pm 0,05 \mathrm{mkg} / \mathrm{ml})$, and $\mathrm{Mg}(14,5 \pm 0,06$ $\mathrm{mkg} / \mathrm{ml})$ compared to children born by somatically healthy mothers.

The development of pathological processes causing embryo and fetus suffering significantly depended on the state of microelement metabolism which frequently affected other metabolic processes in an organism. Thus in the umbilical cord blood of children with prenatal hypoxia $(81,2 \%)$, we observed increased levels of copper against the background of lower levels of the essential zinc, iron, calcium, magnesium $(\mathrm{p}<0.05)$. Fe levels were up to $0.65 \mathrm{mkg} / \mathrm{ml}$ in the newborn suffering chronic hypoxia of a heavy degree $(p<0.05)$. The imbalance of trace elements in the blood of the newborn also resulted from the entry of toxic heavy metals cadmium and lead, concentrations of which correlated with the degree of hypoxia $(\mathrm{p}<0.05)$. 
$\mathrm{Zn}, \mathrm{Fe}$ and $\mathrm{Mg}$ are known to induce the synthesis of metal tioneines which bond the excessive lead and detoxicating it. As the levels of these metals were low in the blood of the newborn this effect was absent. The deficiency of the essential elements $(\mathrm{Cu}, \mathrm{Fe}, \mathrm{Zn}, \mathrm{Mg}, \mathrm{Ca})$ and the selective accumulation of toxic microelements $(\mathrm{Cd}, \mathrm{Pb})$ in the umbilical cord blood were the reason for prenatal fetus suffering, low body mass at birth, the child's growth development retardation. This conclusion was supported by our research on the physical development and health of the newborn of the city. The established correlation between the levels of heavy metals and physical development indices evidenced by the injurious complex effect of high concentration of $\mathrm{Cu}, \mathrm{Zn}, \mathrm{Pb}$ on the body mass $(\mathrm{r}=-0.98 ; \mathrm{r}=-0.98 ; \mathrm{r}=-0.80$ accordingly, $\mathrm{p}<0.05)$ and those of $\mathrm{Cd}$ on the fetal growth $(\mathrm{r}=-0.79 ; \mathrm{p}<0.05)$. This effect caused the failure of early adaptation of the newborn and subsequent health deviations. The disturbance of growth and development of the fetus and newborn was often the reason for the prenatal death, difficult early neonatal adaptation of children and many diseases in the future. The analysis of the material showed that in the basic group of the newborn $72,2 \%$ had the risk of prenatal infection, in the control group - $100 \%$ and $8,5 \%$ - had prenatal intoxication.

\section{Conclusions}

The polluted environment of Ekaterinburg is a constant source of a complex entry of xenobiotics - lead and cadmium - into organisms against the background of the deficiency of the essential trace elements (copper, zinc and iron). The analysis of our data allows us to state that increased levels of heavy metals in the environment have a combined effect on organisms of pregnant residents and cause a high risk of prenatal fetal suffering.

The ecologically unfavourable urban environment promotes changes in physiological and biochemical processes underlying prepathology and pathology. Women of Ekaterinburg have indices of ecological valency, disturbance of reproductive functions and pregnancy complication (hestoses, anaemia, threaten pregnancy interruption). $80 \%$ of the inspected woman had somatic pathology. Among diseases the leading were anaemia, chronic infectious-inflammatory diseases, kidney and endocrine diseases, various forms of mastopathy. Fetoplacental insufficiency, complicated pregnancy and delivery, postnatal complications unfavourably affect the newborn's state. Therefore, health protection, especially protection of health of women and the newborn in conditions of ecologically unfavourable regions including the Urals is priority.

\section{References}

[1] Onishchenko G.G., The effect of environmental conditions on the population health, unsolved problems and aims. Hygiene and sanitary, 1, pp. 3-8, 2003. 
[2] Rahmanin N.V, Revazova JA., Ivanov S.I., Novikov S.M., The actual problems of human ecology and the environment hygiene. Vest. Med. Acad. Sci. Ural. Div, 2. pp. 18-23, 2005.

[3] Oberlis D., Kharland B., Skalny A., The biological role of trace elements of a Man and animals, Nauka: St.-P-burg, 2008.

[4] Avtsyn A.P., Zhavoronkov A.A., Rish M.A., Strochkova L.S., Microelements of a Man: an aetiology, classification, organopathology. Medicine: Moscow, 1991.

[5] Agadzhanyan N.A., Adaptation medicine and health. Vest. Med. Acad. Sci. Ural. Div, 2 pp. 10-18, 2005.

[6] Bolshakov V.N., Mikshevich N.V., Peredery O.G., Ecological evaluation of the work of enterprises of nonferrous metallurgy, Manual - Poligrafist: Sverdlovsk, 1986.

[7] Kovalchuk L.A., Ecologo-physiological aspects of adaptation to conditions of technogenic ecosystems, NISO Ural Div.RAN: E-burg, 2008.

[8] Kovalchuk L.A., Satonkina O.A., Tarkhanova A.E., Heavy metals in the environment of the Middle Urals, their influence on an organism. Ecology, 5, pp. 358-361, 2002.

[9] Regional peculiarities of sanitary-and-epidemiological situation in Sverdlovsk region. GUSCMSR: E-burg, 2008.

[10] Ailamazyan E.K., Savitsky G.A., Beljaeva E.V., Vinogradova E.G., The role of ecological and industrial factors in formation of a of reproductive function pathology in women. Vest. Rus. Ass. Obst. and Gynec, 2, pp. 13-16, 1996.

[11] Skalny A., Odinayeva N., Lukoyanova O. Trace elements in the newborn and their mothers from different regions of Russia. Proc. $2^{\text {nd }}$ Int. Symp. on trace elements in human and new perspectives. Athens, 1999.

[12] Strizhakov A.N., Timohina T.F., Bayev O.R., Phetoplacental insufficiency: pathogenesis, diagnosis, treatment. Problems of Gynec., Obst., and Perinatology, 2(2), pp. 53-56, 2003.

[13] Eichhorn G. L., Intra metal ions and genetic regulation. Metabolism of trace metal in man, Ed. O. M. Rennert., W. Y. Chan, Boca Raton, pp. 1-6, 1984,

[14] Kirchgessner M., Underwood memorial lecture. Homeostasis and homeorhesis in trace element metabolism. Trace elements in Man and animals (Tema - 8). M. Anke., D. Meissner., C.F. Mills (eds). Dresden, pp. 4-21, 1993.

[15] Schrauser G.N., The discovery of the essential trace elements: An outline of the history of biological trace elements research. Biochemistry of the ultratrace elements. Ed. E. Freiden, Plenum Press: New York, London, pp. 17-32, 1994.

[16] Trakhtenberg I.M., A book about poisons and poisonings. Toxicology sketches.- Kiev: Naukova Dumka, 2000.

[17] Diperman A.A., The .role of environment contaminants in the disturbance of embryonal development, Medicine: Moscow, 1980. 
[18] Tarkhanova A.E., The effect of anthropogenic factors on formation of fetus and newborn hypoxia of women dwelling in a big industrial center. A.R. Diss.: Samara, 2004.

[19] Tarhanova A.E, Kovalchuk L.A., Peculiarities of spectrum of essential amino acids in the blood plasma in women with physiological pregnancy in conditions of an industrial city. Vest. Med. Acad. Sci. Ural. Div, 2(25), pp. 171-172, 2009.

[20] Skalny A., Diagnostics and preventive of microelementoses based on the results of medico-ecological inspection. Bases of system analysis in ecologo-hygienic studies. St-P-burg, 2000.

[21] Boev V.M., Environment and ecologically caused disbalance of microelements in the population of urbanised and rural territories. Hygiene and Sanitary, 5, pp. 3-7, .2002.

[22] National Integrated Programmes on Environment and Health in Countries of Central and Eastern Europe (CCEE) / Coddon D., Yoldsmith Y., Yedrichovski W. et al, Moscow, 1994.

[23] Trakhtenberg I.M., Kolesnikov V.S., Lukovenko V.P., Heavy metals in an environment: Modern hygienic and toxicological aspects Навука і тэхніка: Minsk, 1994.

[24] Shtabsky B.M., Xenobiotiks, homeostasis and chemical safety of people. Lviv, 1999. 